\title{
Analysis of National Law in the Market
}

\begin{abstract}
Yichen Yao
Fairmont International School (Shanghai), Shanghai, 201100, China

*Corresponding author.Email:wxz_dgkhsh@abchina.com

ABSTRACT

Due to the lack of perfect legal control, there are many drawbacks in the market. However, although several legal provisions are also included, and the whole market presents a prosperous scene. With the improvement of the law, there will be criminals constantly improving the means of crime, as they are still willing to take great risks to obtain huge profits. In international trade, it is inevitable to encounter the problem of currency exchange between countries. Criminals are likely to enter the market where legal air strikes may occur and carry out dangerous operations. Once they succeed, the huge amount of money will pose great risks to the foreign exchange market, even the whole social market. A simple comparative analysis of the differences between Chinese and American laws, as well as their restrictions on the foreign exchange market are made in this paper. With the gradual improvement of various laws and regulations in today's society, the restriction boundary of foreign exchange market has gradually become more reasonable and effective. In the future, the author will make further study to analyze the differences and the reasons between China and the United States on control of foreign exchange market.
\end{abstract}

Keywords: Epidemic situation, Foreign exchange market, Nike, Law, National data analysis, Factors

\section{INTRODUCTION}

Nowadays, the growing prosperity of international commerce makes lots of people trade through the platforms of foreign exchange market. Some are personal transactions, without large amount involved; while some are enterprise trade, involving a huge amount of money. This huge amount of money could have great hidden danger on the foreign exchange market, even the whole social market. Therefore, the author intends to analyze from the perspectives of enterprises, the state and its laws, in order to explore whether the limited boundary of foreign exchange market in laws and regulations is reasonable and effective.

\section{ANALYSIS OF THE PROBLEMS - TAKING NIKE AS AN EXAMPLE}

Currently, with the rapid development of various technologies, various large enterprises are pouring into the "black hole" of international trade. People attach importance to the great benefits that enterprises bring to themselves in international trade, such as fame and wealth, vanity, money and other practical interests. Through the promotion of products, large enterprises can let more people know their brands, so as to achieve great profits. However, in international trade, it is inevitable to meet the problem of currency exchange rate conversion between countries. In order to analyze the problems specifically, the author takes Nike as an example.

Nike is the most famous sporting goods manufacturer in the world. It produces a variety of sporting goods, including clothing, footwear, sports equipment and other supplies. As one of the world's top 500 "aircraft carriers", Nike's annual business income exceeds 1.5 billion US dollars [1]. Through its financial report, we can see its offline stores in North America, EMEA (Europe, Middle East and Africa) and APLA (Asia Pacific and Latin America) were closed due to COVID-19, slowing the growth trend in China. The following figures show the data for the three years which ended on May 31. 


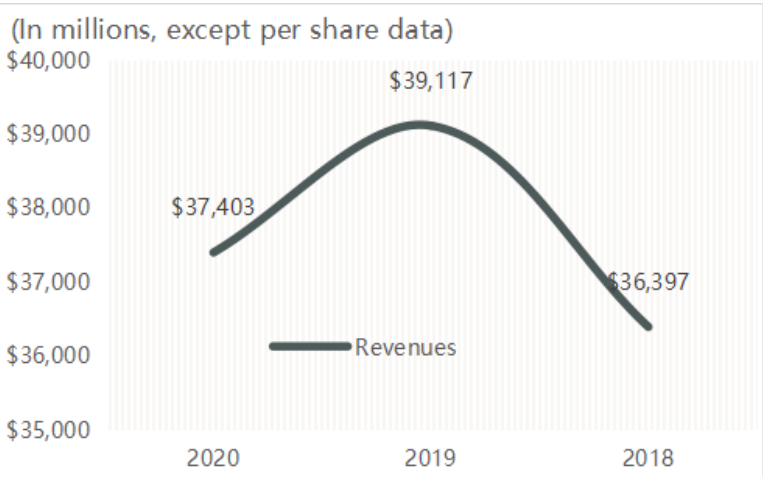

Figure 1 Nike's revenue in 2018-2020

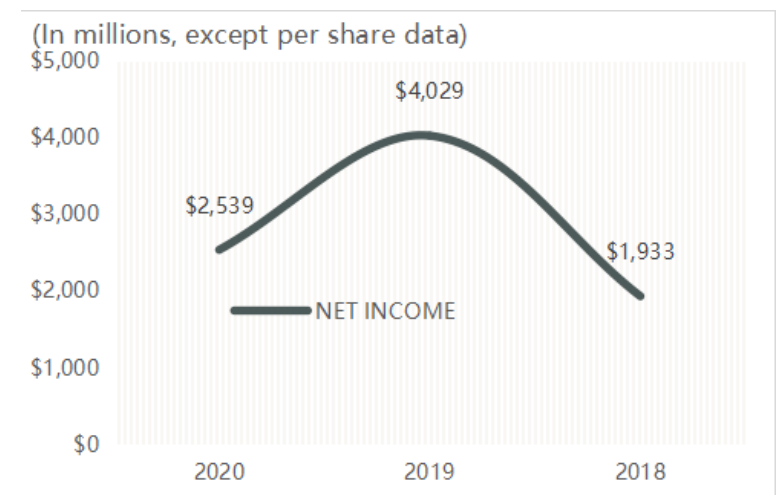

Figure 2 Nike's net income in 2018-2020

Its production and operation activities cover six continents and 150 countries in the world. In addition, it employs 22,000 people and works with nearly 1 million suppliers, shippers, retailers and other service personnel. Indeed there is no big mistake in Nike's cash flow. Looking at the overall situation of Nike, several questions come into the author's mind: will large companies make high returns for themselves through the exchange rate changes in international trade, that is, irregular profits? Will it appear in the company's financial statements?

\subsection{Control of Individuals by Law}

Big companies like Nike can make a lot of profits in international trade. Because it is a foreign enterprise, it involves foreign currency business. Therefore, the exchange rate changes are reflected in its financial statements. So the author does not think it is too big for people to get high returns for themselves under this kind of situation. However, if someone really finds a loophole: making high returns through foreign exchange business of large enterprises, the national government may not have corresponding countermeasures to stop it in time and minimize possible losses. When this situation is feasible, people can make repeated transactions through the exchange rate changes of different countries to achieve the purpose of earning high price difference. For example, the exchange rate conversion between us dollar and RMB is unstable. Due to changes in political and financial markets, the exchange rates of the US dollar and RMB fluctuate frequently. Some people make money through normal stocks and funds. Some people may directly exchange RMB for US dollars or US dollars for RMB to earn the price difference. In this process, the individual amount of dollars can be exchanged is limited by the laws and regulations, and the personal wealth is not strong enough to shake the market economy.

\subsection{Control of Chinese Law on People}

According to Chinese law, "Individuals purchase foreign exchange within the prescribed limit for private use of foreign exchange. Individuals exceeding the prescribed limit shall apply to the foreign exchange administration for private use of foreign exchange. If the foreign exchange administration considers the application to be true, it may purchase foreign exchange. Individuals carrying foreign exchange into and out of the country shall go through the declaration procedures with the customs; if the amount of foreign exchange carried out exceeds the prescribed limit, a valid certificate shall also be issued to the customs" [5]. Therefore, on the basis of Chinese laws, the author thinks that China's restrictions on the foreign exchange market are relatively safe and stable.

\subsection{Consequences of Government's Failure to Control the Foreign Exchange Market}

Unfortunately, even in China, there are still opportunities for people or enterprises. The average individual can convert his own currency within an appropriate amount. Government restrictions on individuals are safe and reliable. In contrast, companies can exchange RMB for US dollars by applying for proper foreign exchange business. The amount of money that a company has is far greater than the amount of money that an individual has at his disposal. Once a company tries to make a difference for itself in this way, the consequences are unimaginable. When a large enterprise obtains a high profit, its cost, manpower, material resources, and sales will have different degrees of change. In short, the amount of a company's single transaction is much higher than that of an individual, so it can be considered that the company has the ability to have a severe impact on the overall market economy where it is located in. Severe impact on the market may lead to inflation in the country. The extent to which the country's currency will rise or fall is unpredictable, which will have a huge impact on people's lives. Poor people will starve to death if they can not afford to eat. Rich people try to transfer their savings to other countries that are safe, which may cause the population loss of the country. For the country, it is not only a small blow, but also a series of continuous deterioration that all countries are trying to avoid. 


\section{FACTORS THAT INFLUENCE CHANGES IN EXCHANGE RATE}

There are several important factors that need to be considered when analyzing the overall data of the country.

\subsection{GDP}

Firstly, GDP is the gross domestic product [2]. It is the final result of the production activities of all permanent establishments of a country or region in a certain period of time, which is calculated according to the national market price. This indicator is recognized as the best indicator to measure the state of the country's economy. The rapid growth of GDP in any country can reflect the vigorous economic development of the country. With the increase of national income in the country, its consumption capacity is also increasing. In this case, the country's central bank will likely raise interest rates and tighten the money supply. The country's overall economic performance and rising interest rates will make the country's currency more attractive. On the contrary, if a country's GDP shows negative growth, it shows that the country's economy is in recession. The consumption power of the people in the country has decreased. At this point, the country's central bank may cut interest rates to stimulate economic growth. However, falling interest rates and sluggish economic performance have made the country's currency less attractive. For example, between 1995 and 1999 , the average annual growth rate of GDP in the United States was $4.1 \%$. The GDP of most countries in the Euro zone is much lower than that of the United States. This has prompted the Euro to show a downward trend against the US dollar since it was launched on January 1, 1999. Generally speaking, high economic growth rate will promote the rise of national currency exchange rate, while low economic growth rate will cause the currency exchange rate to fall.

\subsection{GNP}

Secondly, GNP is the gross national product [3]. GNP is the final result of the initial income distribution of all resident units in a country or region within a certain period (usually one year). It is equal to GDP plus net factor income from home and abroad. Compared with GDP, GNP can better reflect the real economic situation of a country in that GDP includes the income generated by foreign companies at home, which eventually flows into foreign countries. Both GDP and GNP are used to measure the degree of economic development of a country. However, the emphasis of the two is different. GDP emphasizes the value added created, which is production. GNP emphasizes the original income obtained. Scholars are debating which is more important, GDP or GNP. Instead of discussing the importance of both of them, more attention will be paid to the impact on the foreign exchange. If a country or region pays more attention to the value of GDP in its economic policy, it means that it will pay more attention to the maturity and development of its own industry. Both domestic and foreign enterprises support the development of these industries. As it should be, with the growth of GDP, the government will also have corresponding taxes. If a country or region pays more attention to the value of GNP in economic policy, it means that not only the domestic industry should develop, but also the domestic enterprises should support the development of the domestic industry. As a result of this, this country should increase taxes and make real profits. Compared with the private enterprises, the latter will pay more attention to the development of state-owned enterprises.

\subsection{Life Happiness Index of People}

Thirdly, people's life happiness index also has a certain impact on exchange rate changes. When people's life happiness index rises, people's desire to buy will also increase. On the contrary, when people's life is not satisfactory, people's consumption level will also decline. All factors will be more or less complementary. In a country, people's living standard is closely related to the overall economic situation of the country; there is also the exchange rate conversion between countries. Generally speaking, the proper management of a country not only affects the people in this country, but also the people around the world. The butterfly effect theory is applicable to this.

\section{DISCUSSION AND SUGGESTIONS}

Through a general understanding of the laws of the United States and China, it can be found that there are many differences between them. There are two sets of laws in the United States, federal law and state law. Each state has a different law so in some states, and the laws may even conflict. In China, there is only one set of laws, which are formulated by the people's Congress. The American law is very detailed. But every state may have different laws. If the term of imprisonment is more than 20 years, it can be accumulated to even 200 years. China's legal provisions are very rough. Most of the time, the judge's judgment can change the result. The death penalty is nothing but shooting and injection. China belongs to the civil law system and is a written law. The United States belongs to the common law system, which is case law. Case law is also known as "unwritten law", because the rules established by court decisions are often not clearly written. In the United States, both the federal and the states have their own legal systems. Except for national defense, foreign affairs and interstate commerce, the federal government has no unified legislative power; the legislative power of 
criminal and civil and commercial affairs basically belongs to the states. Understanding the differences between the laws of China and the United States, the following part will make a rough analysis and discussion on the foreign exchange market from three aspects: cash flow and national debt, online trading, and international law.

\subsection{Cash Flow and National Debt [4]}

The influence of a country's Treasury on the country cannot be described as small. The whole cash flow of a country has a great influence on its overall market operation. Cash flow refers to the amount of cash outflow and cash inflow in the whole life cycle of an investment project. When enterprises want to survive in the fierce competition market, it is necessary to strengthen cash flow management. For example, in 1975, W. T. grant, one of the largest commercial enterprises in the United States, declared bankruptcy. In the year before its bankruptcy, however, its net operating profit was nearly $\$ 10$ million. Its operating activities provide more than $\$ 20$ million in working capital and \$600 million in bank loans. In 1973, the company's shares were still sold at 20 times their earnings. The reason for the bankruptcy of the company is that the net cash flow of the company has been negative five years before the bankruptcy. Despite the high profits, the company's cash can not pay the huge production expenses and debt expenses. Finally, it leads to "growth bankruptcy".

National debt is the relationship between creditor's rights and debts formed by the state's credit, in accordance with the general principles of debt, by raising funds from the society. Compared with ordinary bonds, national debt is a debt certificate issued by the central government to investors, promising to pay interest and repay the principal at maturity. Therefore, national debt is recognized as the safest investment tool.

\subsection{Online Transactions}

Nowadays, with the rapid development of virtual currency, many transactions have been transferred from offline to online. More and more people are used to only take mobile phones out. Whether it is payment or communication, people gradually tend to use mobile phones for operation, which gives a huge development opportunity for digital currency. The National Bureau of statistics initially used the collected tabular data for aggregate analysis to obtain information such as GDP, GNP, and national cash flow status. Now, they can directly use the Internet to analyze and compare these huge and complex data. They can draw conclusions faster so that the government can adjust its governance strategy in time. So is the foreign exchange market. More and more enterprises will choose to export products abroad after they have developed to a certain extent. This involves currency exchange rates. The government will adjust existing policies after obtaining data and field surveys. But can someone escape the law? After all, as an old saying goes, "if the law does not specify it, it is not a crime; if the law does not specify it, there will be no punishment." With the gradual improvement of various laws and regulations in today's society, the restriction boundary of foreign exchange market is undoubtedly reasonable and effective.

In many countries, state-owned enterprises also account for a large proportion. The amount of funds involved in the operation of state-owned enterprises must be very large, regardless of their profits and losses. Foreign cooperation projects of state-owned enterprises will involve currency exchange rate conversion. Foreign cooperation projects are carried out step by step according to the process, which will involve many people's decisions. In this process, there may be some illegal elements to intervene and make some minor changes, which may lead to the illegal elements making a lot of money when the final decision is passed. During this period, it is very important to test whether the overall national regulatory capacity is in place. Will there be management mistakes in enterprise management? Once the management's decision-making is wrong, the company may face bad public opinion and lose people's trust in the company. In this case, the necessary personnel must be replaced in time. Otherwise, the whole deterioration may be extended to the whole country and even the whole world, and all economic conditions will have an unpredictable impact.

Existing laws should be able to regulate all people, including senior members of society, to a large extent. However, there will still be stars who evade taxes, corruption and smuggling. Government officials and gangs will launder money for themselves through certain means. Government laws should be improved. Or increase the penalty, so that others fear, no longer crime.

\subsection{National Laws}

People need to get the approval of the financial regulators of the two countries for conducting legal foreign exchange transactions.

\subsubsection{Common Laws and Regulations}

There are some general provisions in the law on the foreign exchange market.

"Every foreign exchange broker or platform must hold a valid license to conduct business in the country where you live. If they don't, you may be trading illegally." Everyone's trading behavior should be under the supervision of relevant government agencies. In this way, the state can reasonably manage the overall 
economic operation of the country and avoid major mistakes.

"Every licensed foreign exchange dealer or broker must be subject to periodic review and audit to ensure that it strictly complies with national regulations and industry standards." Every legitimate broker needs to be inspected regularly to ensure that everything is done safely. In order to prevent middlemen from being bribed by malicious forces because of greed or other reasons, they make acts threatening national security.

"The law requires foreign exchange brokers to perform their contracts with each trading client. The state protects the legitimate interests of citizens through reasonable legal provisions. By preventing and eliminating the possible dangers in advance, citizens can get a relatively safe and comfortable social environment.

"A key feature of foreign exchange regulation is that each foreign exchange broker must have sufficient funds to pay for the client's investment." Letting the broker deal with the client without cheating is another layer of customer protection to effectively prevent customer from property loss.

Under the supervision of so many laws and regulations and executors, the restriction boundary of foreign exchange market is reasonable and effective.

\subsubsection{US Foreign Exchange Trading [6]}

The United States is the largest economy, reflected in GDP and wealth. It also has the largest stock exchanges: the New York Stock Exchange and NASDAQ. However, US foreign exchange trading regulations strictly stipulate that only some securities companies can publicly sign contracts with American traders to finance their trading accounts. Therefore, it may be difficult for US foreign exchange traders to finance new trading accounts. The territory of the United States and the corresponding population size are enormous. Its economy, science and technology are very advanced. In addition, the US dollar is the most traded and used reserve currency of all currencies. Strict financial regulation scares away many foreign exchange brokers. As a result, only a few brokers can accept us traders. However, the US foreign exchange market still attracts traders as it trades more than $\$ 6$ trillion a day.

Traders who have been exposed to foreign exchange transactions can participate in the US foreign exchange market legally. As long as they pay the usual taxes. However, the brokerage business is still closely monitored by US regulators. To provide services to traders in the United States, brokers must hold a license in the US. After all, for example, EU foreign exchange brokers also submit license applications to their respective foreign licensing authorities. In the United States, however, the minimum amount of capital held is so high that only a few people can legally operate there. These requirements first appeared in the DOD Frank act of 2012, which more or less covers all financial services sectors. In 2010, under the protection of the Wall Street act, the reform was formally put into effect by Obama. It aims to reform the financial regulatory system after the 2008 financial scandal. The law is considered to be one of the most comprehensive reforms of the US financial system. The bill sets out the key rules governing currency trading activities. Some of the restrictions include: leverage cap: 50:1 for major currency pairs and 20:1 for foreign currency pairs. These rules also limit hedging. It is a trading technique. It involves double trading on the same currency pair at the same time to reduce losses caused by loss making transactions. Another requirement is for residents to file a mandatory annual tax return: $60 \%$ of profits are considered capital gains and the tax rate is $15 \%$. The remaining $40 \%$ may be subject to tax, depending on the income level of the trader. Finally, after the DOD Frank act was enacted, the harsh demands scared many companies away. According to them, brokers need to get a license and have a \$20 million margin. In contrast, brokers in Europe only need to prove that they have between $\$ 100,000$ and $\$ 500,000$ in cash. This is obviously a huge deterrent, because of these strict requirements, most brokers decided to abandon the U.S. market.

\section{CONCLUSION}

In short, the country's long-term prosperity means the continuous improvement of national laws and policies. After the improvement of laws and regulations, the limitation boundary of foreign exchange market is effective and reasonable. At the same time of perfecting the law, the illegal behavior of malicious criminals will be further improved. In order to curb this situation, the government must try its best to improve the law before the violators find a solution. Compared with domestic transactions, foreign trade projects in the foreign exchange market are more likely to be used by criminals. Therefore, the legal provisions of the foreign exchange market are particularly important. There are still some deficiencies in this study, for example, there are no clear legal provisions behind the examples, and the legal comparison between China and the United States is not very complete. In the future, the author will track the similarities and differences between the two countries in law, and further study the differences in foreign exchange market restrictions between the two legal systems (civil law system and common law system).

\section{ACKNOWLEDGMENTS}

From the topic selection of the thesis, to the collection of materials, and then to the completion of the final paper, I am very honored to get the warm help and encouragement of many friends. First of all, I want to thank my parents and friends. They gave me a lot of 
critical comments at the beginning of my thesis topic selection. Secondly, I would like to thank you, Ms. Erica and Ms. Jane. After class, the teachers will patiently answer all my questions. Whether in thought or in study, I have been warmly encouraged and concerned, so that I can regain confidence in the face of setbacks. Finally, I would like to thank my parents and friends again. Thank them for all their useful suggestions and comments. Thank them for their help in the process of writing the paper, so that I can successfully complete the paper. Thank them for their support and help in my life!

\section{REFERENCES}

[1] JDI team, "Nike Market Analysis Report", April 11, 2011, p.4

[2] GDP, 2019 Pearson Education, Ltd. All Rights Reserved, pp.576\&586\&589

[3] GNP, 2018, 2015, 2012, 2009 by Barron's Educational Series, p.210

[4] Cash Flow, Y. F. Wang, Principle of accurate preparation of cash flow statement, Beijing, China finance and Economics Press, August 2004, pp.1-5

[5] Regulations on the Foreign Exchange System of the People's Republic of China, August 1, 2008, Article 14

[6] Forex brokers in the United States and trading regulation, retrieved from Forex-Central.net on November 15, 2020 